\title{
Service Availability and Readiness Assessment (SARA) of Health Facilities in Moyamba District Southern Province of Sierra Leone
}

\author{
Brima Gegbe $^{1, ~ *, ~ B o b ~ K a n d e h ~}{ }^{1,2}$, Andrew Baimba ${ }^{1,3}$ \\ ${ }^{1}$ Department of Mathematics and Statistics, Njala University, Freetown, Sierra Leone \\ ${ }^{2}$ Office of Pro-Chancellor, Njala University, Freetown, Sierra Leone \\ ${ }^{3}$ Department of Physics and Computer Sciences, Njala University, Freetown, Sierra Leone \\ Email address: \\ bgegbe@njala.edu.sl (B. Gegbe), boborsama@njala.edu.sl (B. Kandeh), baimba2013@gmail.com (A. Baimba) \\ ${ }^{*}$ Corresponding author
}

\section{To cite this article:}

Brima Gegbe, Bob Kandeh, Andrew Baimba. Service Availability and Readiness Assessment (SARA) of Health Facilities in Moyamba District Southern Province of Sierra Leone. Biomedical Statistics and Informatics. Vol. 4, No. 4, 2019, pp. 32-38. doi: $10.11648 /$ j.bsi.20190404.12

Received: December 4, 2019; Accepted: December 18, 2019; Published: December 26, 2019

\begin{abstract}
Sierra Leone needs strong information systems to adequately track progress made and to inform decisions about the implementation of health care programmes as it implements its recovery and resilience plans. A challenge observed with the national health management information system (HMIS) is the quality of routine reports from health facilities and districts. The objective of this research is to assess the service availability and readiness of health facilities in Moyamba district. This research was facility based cross sectional survey. A representative sample of 87 health facilities was selected for the assessment, with an oversampling of hospitals. In this sampling procedure $86 \%$ of the health facilities considered for this research were Government/Public owned facilities and 1.1\% mission/faith owned facilities. Stat graphic 18 was used to do the data analysis. The district has 55\% General Service Index (GSI) for all categories of health facilities. Readiness scores in preventive curative, antenatal care service and malaria services were above $90 \%$ in the district. The least readiness score was high level diagnostic equipment with $1 \%$. Blood transmission services had the least specific readiness score of $4.3 \%$. Government of Sierra Leone to Strengthening capacity of District Health Management Teams to plan, supervise and monitor all health facility programs at district levels.
\end{abstract}

Keywords: General Service Index, Readiness Scores, Percentage Availability, Component, Formatting, Style, Styling, Insert

\section{Introduction}

Sound information on the supply and quality of health services is necessary for health systems management, monitoring and evaluation. Efforts to achieve the Sustainable Development Goals (SDGs) and to scale up interventions for HIV/AIDS, malaria, safe motherhood and child health through global health partnerships, have drawn attention to the need for strong country monitoring of health services, covering the public, private-for profit and private not-for-profit sectors, and their readiness to deliver key intervention [1].

With the increased demand for accountability and the need to demonstrate results at country levels, information is needed to track how health systems respond to increased inputs and improved processes over time, and the impact such inputs and processes have on improved health outcomes and better health status [2].

Sierra Leone, part of global accountability needs strong information systems to adequately track progress made and to inform decisions about the implementation of health care programmes as it implements its recovery and resilience plans. A challenge observed with the national health management information system (HMIS) is the quality of routine reports from health facilities and districts. They are often incomplete, overdue, of inadequate quality and subject to bias. It is imperative to systematically improve the quality of facility-generated data through a well-functioning routine HMIS, complemented by a systematic and periodic facility assessment of service availability 
and readiness, and a record review of selected indicators to fill data gaps and to verify the quality of routinely reported data.

These reviews will inform progress, performance reports, programme planning and policy formulation. The SARA on the district will provide essential information on service delivery by assessing and monitoring service readiness and capacity of health facilities in the district. Assessing the equitable and appropriate distribution of services and resources; and providing the health sector with the skills and tools for monitoring service and resource availability on a regular basis. This research provides essential information on the status of the health system in terms of service accessibility, and the readiness of facilities to provide an adequate level of service (for example, availability of trained staff, diagnostics, equipment and medicines) for both general health services and specific key health interventions (for example, maternal and newborn health, HIV/AIDS, TB, and malaria diagnosis and treatment).

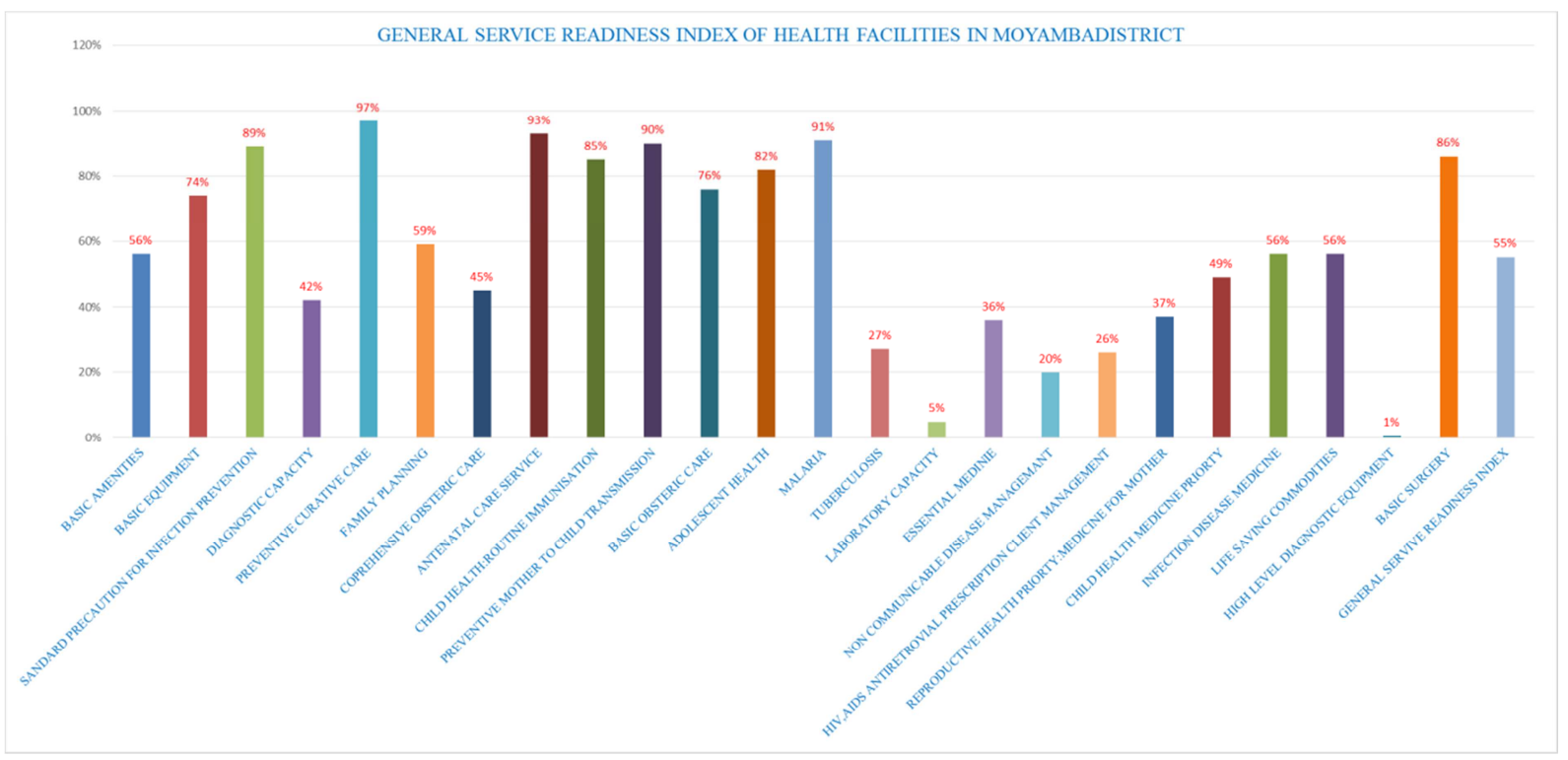

Figure 1. General Service Readiness Index of Health Facilities in Moyamba District.

\section{General Service Readiness Index of Health Facilities in Moyamba District}

Readiness showed the basic requirements to provide services such as amenities, basic equipment, standard precautions for infection control, diagnostic tests, medicines etc. Moyamba district has 55\% General Service Index (GSI) for all categories of health facilities assessed during this research. Readiness scores in preventive curative, antenatal care service and malaria services are above $90 \%$ in the district, while all other readiness scores are below 90\%. The least readiness score is High-level diagnostic equipment with $1 \%$.

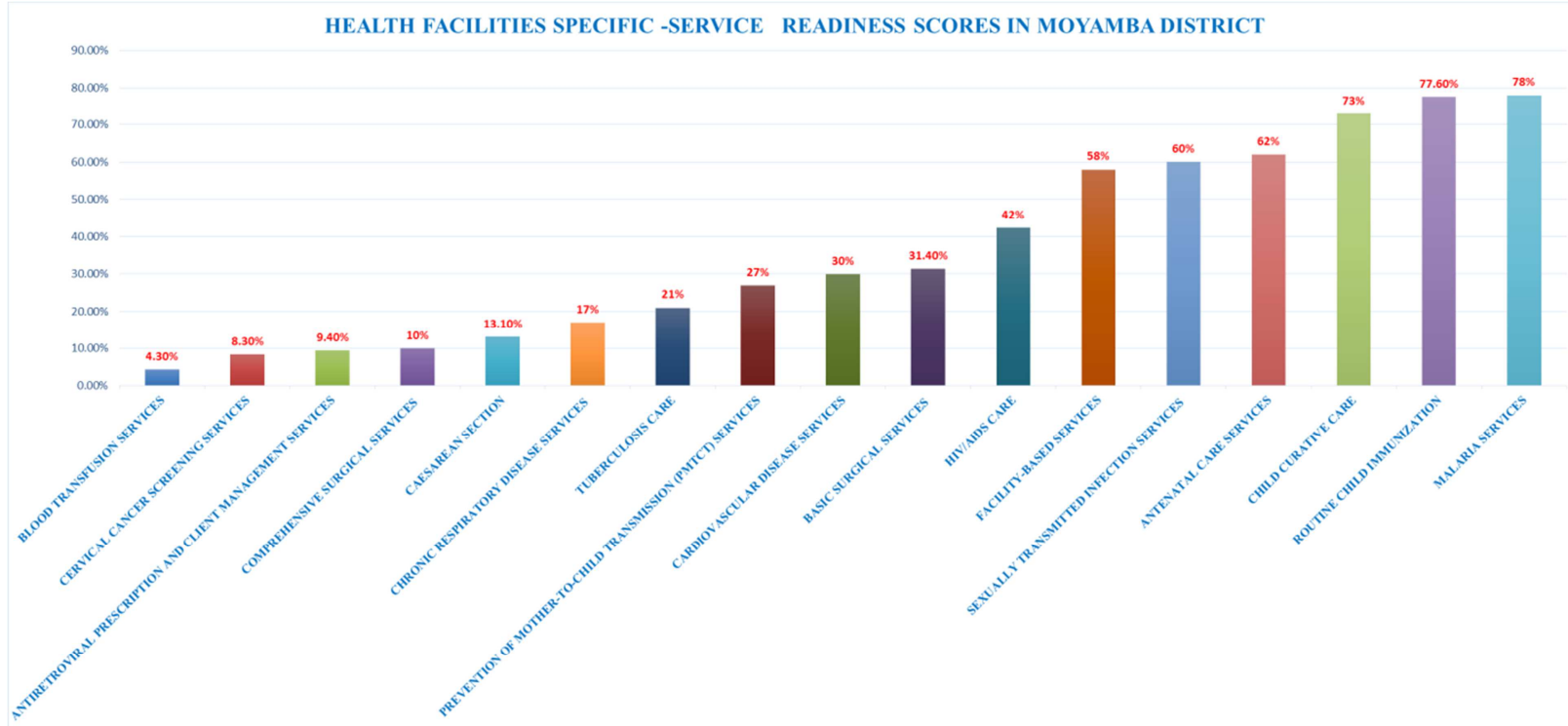

Figure 2. Health Facilities Specific-Service Readiness Scores in Moyamba District. 


\section{Health Facilities Specific-Service Readiness Scores in Moyamba District}

Blood transmission services have the least specific readiness score of $4.3 \%$ compared to all other health facilities in the district. Malaria, routine child immunization and child curative care services are the three top three specific- service readiness scores in Moyamba district with of 78\%, 77.6\% and $73 \%$ respectively. Facility-based, sexually transmitted infection and antenatal care services are the most specific-service readiness scores that are above average immediately after the top highest specific service readiness scores. The rest of specific readiness scores are below overage.

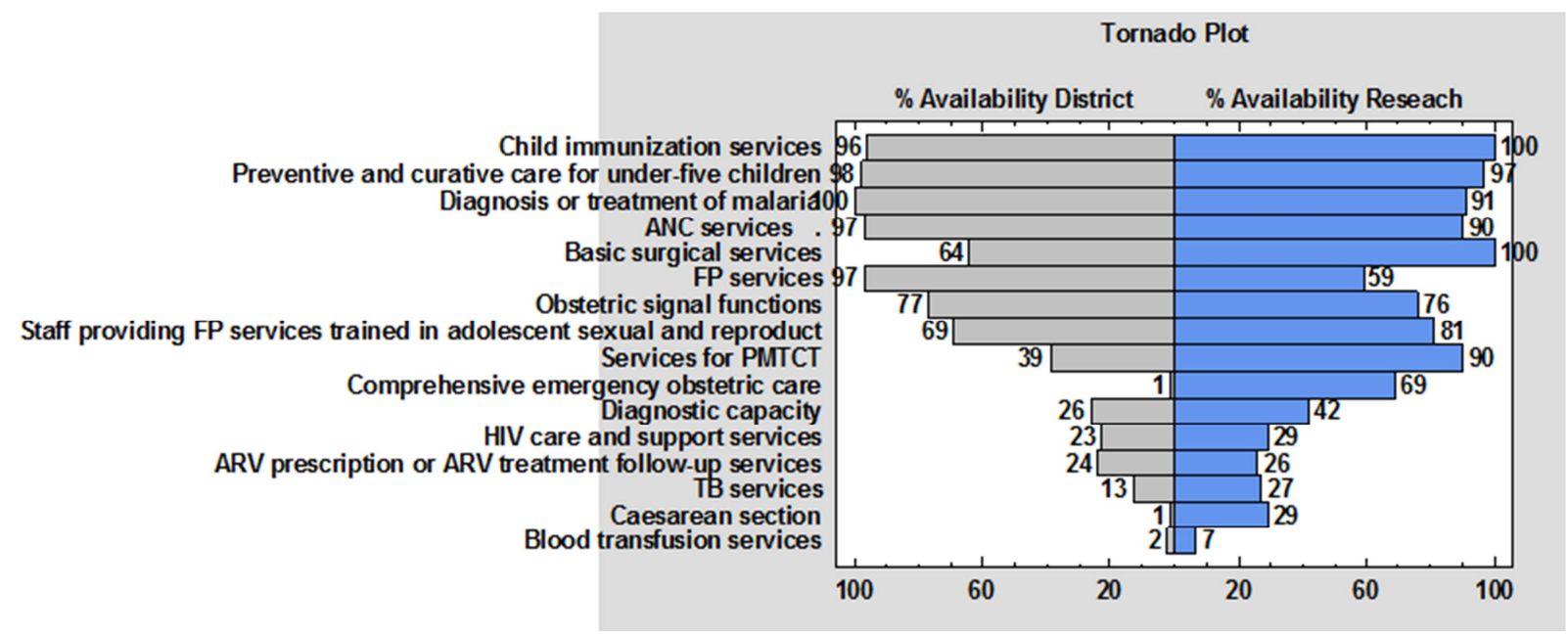

Figure 3. Percentage Availability for Moyamba district (National Data 2017) compared to percentage availability Research data (2019).

\section{Percentage Availability for Moyamba District (National Data 2017) Compared to Percentage Availability Research Data (2019)}

The figure 3 above shows compared percentage availability (Service Availability and Readiness Assessment, Sierra Leone 2017) to my research data (2019). Two years after (national data), child immunization service in the district is now $100 \%$ (research data), caesarean section increased to $29 \%$ (research data), while blood transfusion from $2 \%$ service availability to $7 \%$ (research data) respectively for the district. Basic surgical services increase to $100 \%$ (research data, 2019) from $64 \%$ (national data, 2017).

Table 1. Summary Statistics for percentage availability (research data) compared to percentage availability (national).

\begin{tabular}{lll}
\hline & $\begin{array}{l}\text { \% AVAILABILITY } \\
\text { (National) }\end{array}$ & $\begin{array}{l}\text { \% AVAILABILITY } \\
\text { (Research data) }\end{array}$ \\
\hline Count & 16 & 16 \\
Average & 51.6875 & 63.3125 \\
Standard & 39.2899 & 31.8679 \\
deviation & $76.0143 \%$ & $50.3343 \%$ \\
Coeff. of variation & 1.0 & 7.0 \\
\hline Minimum & & \\
\hline
\end{tabular}

\begin{tabular}{lll}
\hline & $\begin{array}{l}\text { \% AVAILABILITY } \\
\text { (National) }\end{array}$ & $\begin{array}{l}\text { \% AVAILABILITY } \\
\text { (Research data) }\end{array}$ \\
\hline Maximum & 100.0 & 100.0 \\
Range & 99.0 & 93.0 \\
Stnd. skewness & 0.00738842 & -0.634193 \\
Stnd. kurtosis & -1.45369 & -1.18645 \\
\hline
\end{tabular}

\section{Statistics for Percentage Availability (Research Data) Compared to Percentage Availability (National Data)}

Table 1 above shows summary statistics for percentage availabilities for national and research data. This analysis can be used to test whether differences between the statistics from the two samples are statistically significant. Of particular interest, there are the standardized skewness and standardized kurtosis, which can be used to determine whether the samples come from normal whether the sample distributions. Values of these statistics outside the range of -2 to +2 indicate significant departures from normality, which would tend to invalidate the tests, which compare the standard deviations. In this case, both standardized skewness values are within the range expected. Both standardized kurtosis values are within the range expected. 


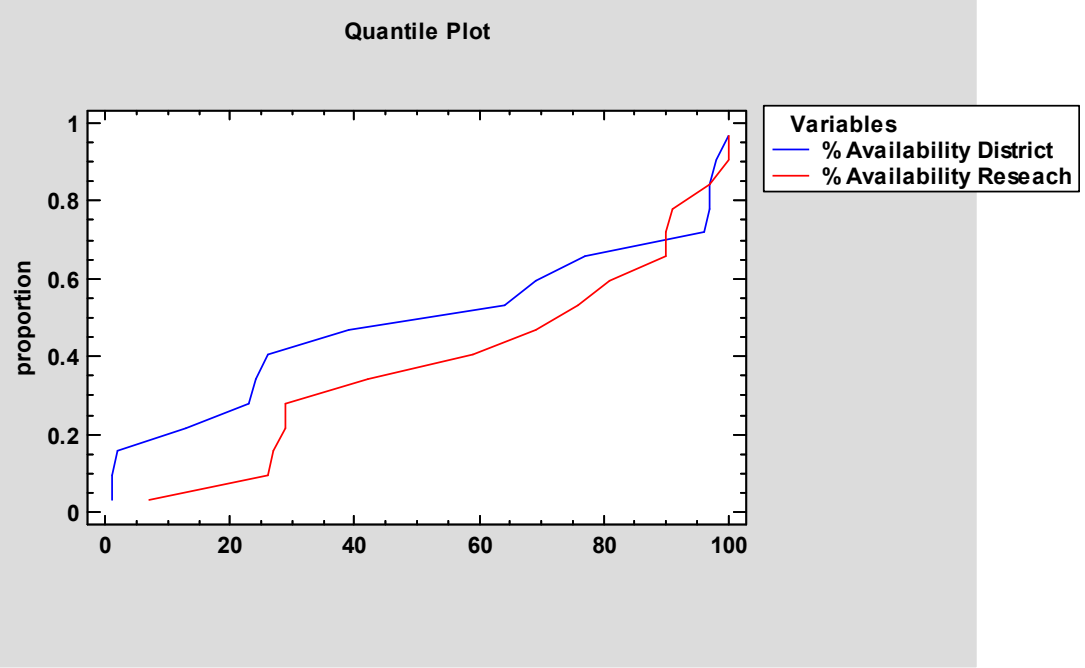

Figure 4. Quantum Plot for Percentage Availability (Research data) Compared to Percentage Availability (National data).

\section{Quantum Plot for Percentage Availability (Research Data) Compared to Percentage Availability (National Data)}

The quantile plot illustrates the proportion of data in each ample that is below a given value of the function $\mathrm{X} 1$ as the function of $\mathrm{X}$. The percentage availability of the research data is close together to the percentage availability (national data) after two years, the overall slopes are similar.

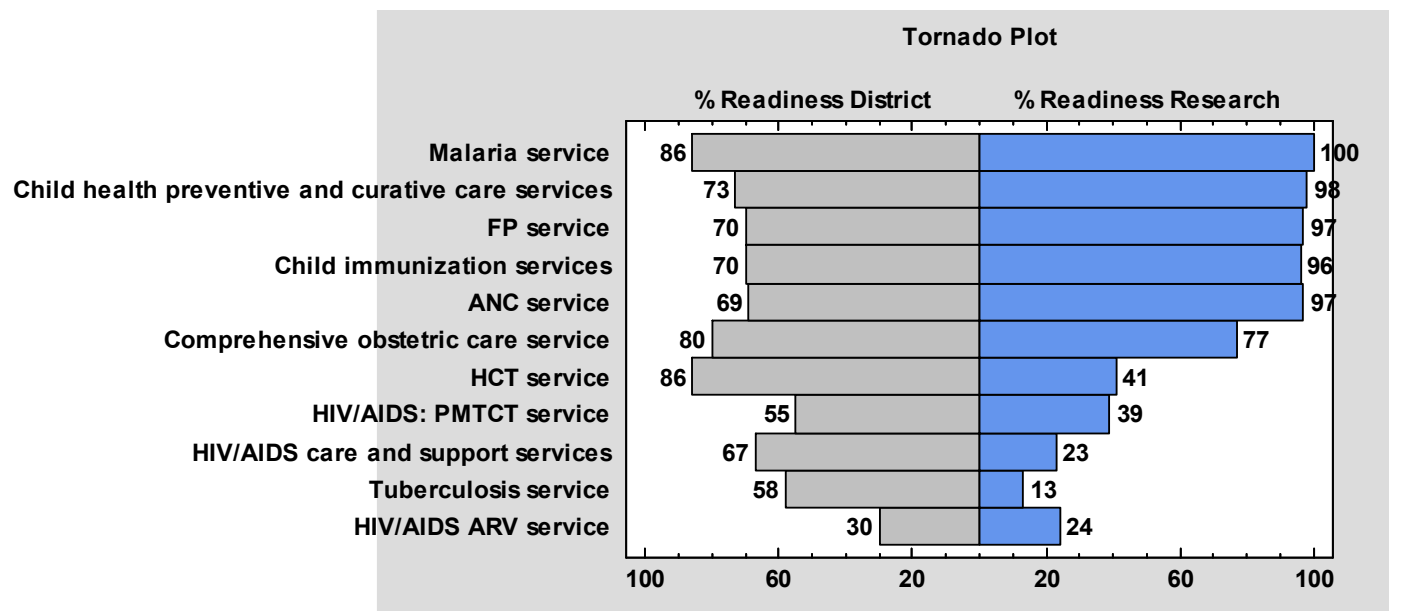

Figure 5. Service Readiness for Research data (2019) compared to Service Readiness for Moyamba district (National Data 2017).

\section{Service Readiness for Research Data (2019) Compared to Service Readiness for Moyamba District (National Data 2017)}

Readiness score (national data 2017) for malaria was $86 \%$ in 2017, two years after is now 100\% (research data, 2019). Service readiness for all facilities in the district increased, unless readiness scores in tuberculosis services, HIV/AIDS, ARV services, HIV/AIDS care and Services and HIV/AIDS: PMTCT, that reduced after two years (Research data).

Table 2. Summary Statistics for Percentage Readiness (Research data) Table: Compared to Percentage Readiness (National data).

\begin{tabular}{lll}
\hline & \% READINESS (National) & \% READINESS (Research) \\
\hline Count & 11 & 11 \\
Average & 67.6364 & 64.0909 \\
Standard deviation & 15.9328 & 35.8593 \\
Coeff. of variation & $23.5566 \%$ & $55.9507 \%$ \\
\hline
\end{tabular}




\begin{tabular}{lll}
\hline & \% READINESS (National) & \% READINESS (Research) \\
\hline Minimum & 30.0 & 13.0 \\
Maximum & 86.0 & 100.0 \\
Range & 56.0 & 87.0 \\
Stnd. Skewness & -1.7089 & -0.373507 \\
Stnd. Kurtosis & 1.59414 & -1.37037 \\
\hline
\end{tabular}

\section{Summary Statistics for Percentage Readiness (Research Data) Compared to Percentage Readiness (National Data)}

This table above shows summary statistics of percentage readiness (Research data) compared to percentage readiness (National data). This analysis can be used to test whether differences between the statistics from the two samples are statistically significant. Of particular interest, here are the standardized skewness and standardized kurtosis, which can be used to determine whether the samples come from normal distributions. Values of these statistics outside the range of -2 to +2 indicate significant departures from normality, which would tend to invalidate the tests, which compare the standard deviations. In this case, both standardized skewness values are within the range expected. Both standardized kurtosis values are within the range expected.

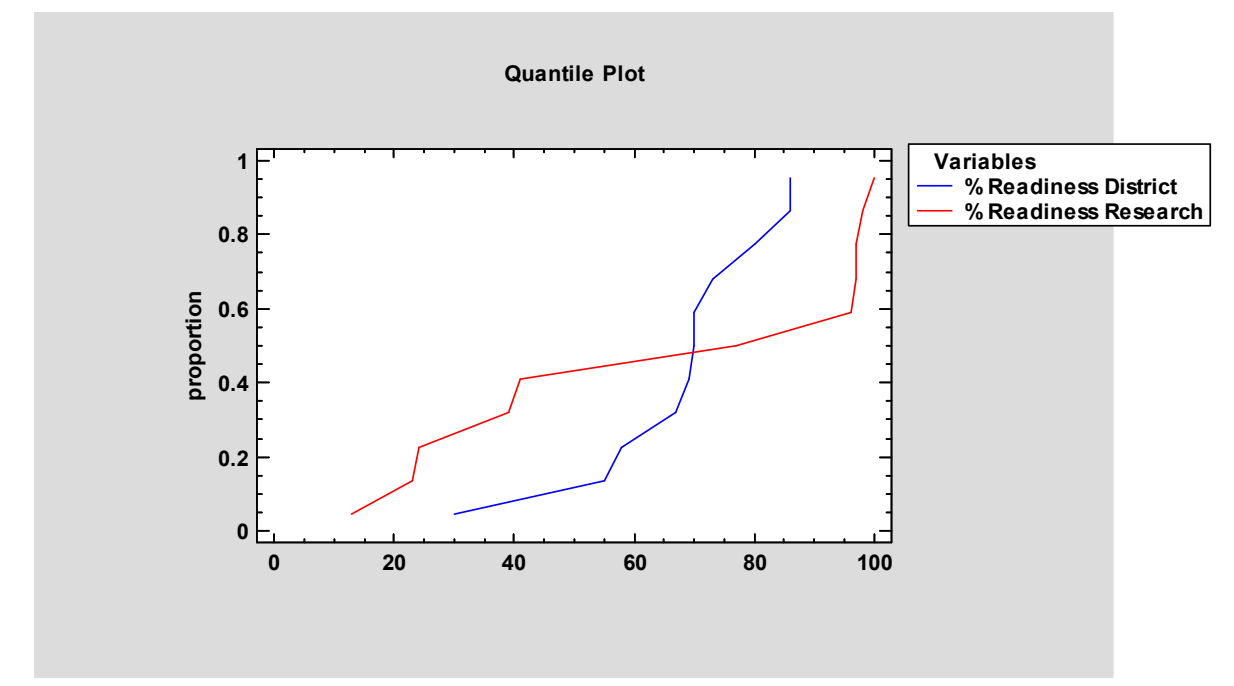

Figure 6. Quantile Plot of Percentage Readiness (Research data) Compared to Percentage Readiness (National data).

\section{Quantile Plot of Percentage Readiness (Research Data) Compared to Percentage Readiness (National Data)}

The sample of the research data for readiness scores are a bit apart from the readiness scores in the national data after two years converged later but tend to be apart again right above, however the overall slopes are similar.

\section{Generalized Linear Models (GLMs)}

Poisson regression is used to predict a dependent variable that consists of "count data" given one or more independent variables. In this research, the dependent variable is the count or number of professional staff in Moyamba district and the predicted variables are: facility type, specialist medical doctors, non-physician clinical paramedical professionals, nursing professionals, midwifery professionals, pharmacists, laboratory technicians (medical pathology) and Community Health Workers. The researcher wants to know if the allocation of health worker per chiefdom in the district for the past year depends or is influence by the type of health facilities and the categories of health professionals in the district.

Table 3. Model and Variable Verification.

\begin{tabular}{ll}
\hline MODEL INFORMATION & \\
\hline & PROFESSIONAL HEALTH \\
Dependent Variable & FACILITY STAFF IN MOYAMBA \\
& DISTRICT \\
Probability Distribution & Poisson \\
Link Function & Log \\
\hline
\end{tabular}

\section{Model and Variable Information}

The table 3 confirms that the dependent variable is the "Number of professional staff in Moyamba district", the probability distribution is "Poisson" and the link function is the natural logarithm. 
Table 4. Test of Models Effect.

\begin{tabular}{llll}
\hline TEST OF MODEL EFFECTS & & & \\
\hline \multirow{2}{*}{ Source } & Type III & df & Sig. \\
\cline { 2 - 4 } & Wald Chi-Square & 1 & .000 \\
(Intercept) & 75.481 & .166 \\
FACILITY TYPE & 3.587 & .230 \\
SPECIALISTMEDICAL DOCTORS & 1.442 & .044 \\
NON-PHYSICIAN CLINICALS/PARAMEDICAL PROFESSIONALS & 4.074 & 1 & .000 \\
NURSING PROFESSIONALS & 19.513 & 1 \\
MIDWIFERY PROFESSIONALS & 9.351 & 1 \\
PHARMACIST & 4.243 & .002 \\
LABORATORY TECHNICIANS (MEDICAL AND PATHOLOGY & 4.169 & .039 \\
COMMUNITY HEALTH WORKERS & 76.932 & 1 & .041 \\
\hline
\end{tabular}

\section{Test of Model Effects}

There is not usually any interest in the model intercept. However, we can see that facility type, specialist medical doctors, non-physician clinical paramedical professionals, nursing professionals, midwifery, laboratory, Community Health Workers are all statistically significant with ( $p$ values of $0.000,0.166,0.230,0.04,0.000,0.02,0.039,0.041$ and 0.000 respectively).

\section{Parameter Estimates}

Table 5. Parameter Estimates.

\begin{tabular}{|c|c|c|c|c|c|c|c|c|c|c|}
\hline \multirow[b]{2}{*}{ Parameter } & \multirow[b]{2}{*}{ B } & \multirow[b]{2}{*}{$\begin{array}{l}\text { Std } \\
\text { Error }\end{array}$} & \multicolumn{2}{|c|}{$\begin{array}{l}95 \% \text { Wald } \\
\text { Confidence Interval } \\
\end{array}$} & \multicolumn{3}{|c|}{ Hypothesis Test } & \multirow[b]{2}{*}{$\operatorname{Exp}(B)$} & \multicolumn{2}{|c|}{$\begin{array}{l}\text { 95\% Wald Confidence } \\
\text { Interval for } \operatorname{Exp}(\mathrm{B}) \\
\end{array}$} \\
\hline & & & Lower & Upper & $\begin{array}{l}\text { Wald } \\
\text { Chi-Square }\end{array}$ & df & Sig. & & Lower & Upper \\
\hline (Intercept) & 1.098 & .1054 & .891 & 1.304 & 108.422 & 1 & .000 & 2.997 & 2.438 & 3.685 \\
\hline [Facility Type=CHC] & -.199 & .1385 & -.471 & .072 & 2.072 & 1 & .150 & .819 & .624 & 1.075 \\
\hline$[$ Facility Type =CHP] & .042 & .1104 & -.174 & .258 & .144 & 1 & .704 & 1.043 & .840 & 1.295 \\
\hline [Facility Type =MCHP] & $0^{\mathrm{a}}$ & - & - & - & - & - & - & 1 & - & - \\
\hline $\begin{array}{l}\text { Clinical/Paramedical } \\
\text { Professionals }\end{array}$ & .206 & .1023 & .006 & .407 & 4.074 & 1 & .044 & 1.229 & 1.006 & 1.502 \\
\hline Nursing Professionals & .094 & .0213 & 052 & .136 & 19.513 & 1 & .0000 & 1.099 & 1.054 & 1.145 \\
\hline Midwifery Professionals & .178 & 0582 & .064 & .292 & 9.351 & 1 & .002 & 1.195 & 1.066 & 1.339 \\
\hline Pharmacist & .080 & .0389 & .004 & .157 & 4.243 & 1 & .039 & 1.084 & 1.004 & 1.169 \\
\hline $\begin{array}{l}\text { Laboratory Technicians } \\
\text { (Medical and Pathology }\end{array}$ & .239 & .1173 & .010 & .469 & 4.169 & 1 & .041 & 1.271 & 1.010 & 1.599 \\
\hline
\end{tabular}

This table provides both the coefficient estimates (the "B" column) of the Poisson regression and the exponentiated values of the coefficients (the "Exp (B)" column). It is usually the latter that are more informative. These exponentiated values can be interpreted in more than one ways.

\section{Conclusion}

The district has 55\% General Service Index (GSI) for all categories of health facilities assessed during this research. The majority of health facilities practiced the required level of infection prevention at the time of the assessment. Health facilities with standard precautions for infection equipment in the district has readiness score of $39 \%$ which is far below average. The expected log count for a unit of professional staff, midwifery, laboratory technicians, Community Health
Workers and nursing profession increase were $0.099,0.195,0.271,0.087$ respectively.

\section{Acknowledgements}

I owe depth of gratitude of God almighty through Jesus for given me knowledge, wisdom and understanding through out my academic pursuit. My sincere thanks go to Professor Bob Kandeh and Professor Andrew Baimba for their lead and quality supervisions for the entire work. I am particularly grateful to my wife for her architectural role in my academic activities. Thanks and appreciation to my mother and late father, they nurtured me to the level I am today. 


\section{References}

[1] W. H. O (Service Availability and Readiness Assessment (SARA) An annual monitoring system for service delivery, 2018).

[2] (SARA, Sierra Leone, 2017).

[3] W. H. O Standards for improving Quality of Mental and New-born Care in Health Facilities. Geneva, Switzerland 2016. Google Scholar.

[4] Use of Service Provision Assessments and Service Availability and Readiness Assessments for Monitoring Quality of Maternal and New-born Health Services in Low-income and Middle Income Countries. British medical Journal, Gobal Health 3 (6): e0001011. November, 2018.

[5] Black Ak Diazc, Mccarthy K, et al. Measuring Progress in Mental and New-born Health Care in Mexico: Validating Indicators of Health Health System Contact and Quality of Care. BMC, Pregnancy Child Birt, 2016, 16: 2555, doi: 1011861S12884-01b-1047-0. Google Scholar.

[6] European Centre for Disease Prevention and Control. (2014 Sept. 29) Outbreak of Ebola virus disease in West.

[7] Africa -rapid risk assessment. Fifth update, [Internet]. Stockholm: ECDC; 2014. Available from: http://ecdc.europa.eu/en/publications/Publications/Ebola-Sierr a\%20Leone-Liberia-Guinea-Nigeria-23-09-2014-rapid-risk-as sessment.pdf.

[8] European Centre for Disease Prevention and Control. (2014 Sept. 3) Outbreak of Ebola virus disease in West Africa - rapid risk assessment. Fourth update. [Internet]. Stockholm: ECDC; 2014. Available from: http://www.ecdc.europa.eu/en/publications/Publications/Ebola -virus-disease-west-africa-risk-assessment-.pdf.

[9] European Centre for Disease Prevention and Control. (2014, Aug. 1) Outbreak of Ebola virus disease in West Africa - rapid risk assessment. Third update, 1 August 2014. [Internet]. Stockholm: ECDC; $\quad$ Available from: http://www.ecdc.europa.eu/en/publications/Publications/ebolaoutbreak-west-africa.

[10] Bhutta ZA, Black RE, Brown KH, Gardner JM, Gore S, Hidayat A, Khatun F, Martorell R, Ninh NX, Penny ME, Rosado JL, Roy SK, Ruel M, Sazawal S, Shankar A: Prevention of diarrhea and pneumonia by zinc supplementation in children in developing countries: pooled analysis of randomized controlled trials, Zinc Investigators' Collaborative Group. J Pediatr. 1999, 135: 689-697.10.1016/S0022-3476(99)70086-7. Google Scholar.

[11] Bhutta ZA, Das JK, Rizvi A, Gaffey MF, Walker N, Horton S, Webb P, Lartey A, Black RE, Lancet Nutrition Interventions Review Group, Maternal and Child Nutrition Study Group: Evidence-based interventions for improvement of maternal and child nutrition: what can be done and at what cost?. Lancet. 2013, 382: 452-477. 10.1016/S0140-6736(13)60996-4.

[12] Bhutta ZA, Das JK, Walker N, Rizvi A, Campbell H, Rudan I, Black RE, Lancet D, Pneumonia Interventions Study G: Interventions to address deaths from childhood pneumonia and diarrhoea equitably: what works and at what cost?. Lancet. 2013， 381: 1417-1429. 10.1016/S0140-6736(13)60648-0. View ArticlePubMedGoogle Scholar.

[13] Bryce J, Arnold F, Blanc A, Hancioglu A, Newby H, Requejo $\mathrm{J}$, Wardlaw $\mathrm{T}$, CHERG Working Group on Improving Coverage Measurement: Measuring coverage in MNCH: new findings, new strategies, and recommendations for action. PLoS Med. 2013, 10: e1001423-10.1371/journal.pmed.1001423.

[14] Bryce J, Requejo JH, Moulton LH, Ram M, Black RE: Population Health I, Training - Africa Health Initiative Data C: a common evaluation framework for the African Health Initiative. BMC Health Serv Res. 2013, 13: S10-10.1186/1472-6963-13-S2-S.

[15] Cairncross S, Hunt C, Boisson S, Bostoen K, Curtis V, Fung IC, Schmidt WP: Water, sanitation and hygiene for the prevention of diarrhoea. Int $\mathrm{J}$ Epidemiol. 2010, 39: i193-i205. 10.1093/ije/dyq035.

[16] Campbell H, El Arifeen S, Hazir T, O'Kelly J, Bryce J, Rudan I, Qazi SA: Measuring coverage in $\mathrm{MNCH}$ : challenges in monitoring the proportion of young children with pneumonia who receive antibiotic treatment. PLoS Med. 2013, 10: e1001421-10.1371/journal.pmed.1001421 Google Scholar.

[17] Center for Disease Control. (2008 Mar. 31) "Summary of Notifiable Diseases. United States, 2006". Morbidity and Mortality Weekly Report. Center for Disease Control and Prevention.

[18] Checkley W, Buckley G, Gilman RH, Assis AM, Guerrant RL, Morris SS, Molbak K, Valentiner-Branth P, Lanata CF, Black RE, Childhood Malnutrition and Infection Network: Multi-country analysis of the effects of diarrhoea on childhood stunting. Int J Epidemiol. 2008, 37: 816-830. 10.1093/ije/dyn099. Google Scholar. 